\title{
PENGARUH PROGRAM KELUARGA HARAPAN (PKH) TERHADAP TINGKAT PENDAPATAN NELAYAN DI KELURAHAN BAGAN HULU KECAMATAN BANGKO KABUPATEN ROKAN HILIR
}

\author{
The Influence of "Program Keluarga Harapan (PKH)" \\ on the Income Level of Fishers at Bagan Hulu, \\ Bangko Sub-Regency, Rokan Hilir Regency
}

\author{
Deviasari, Firman Nugroho, dan *Trisla Warningsih \\ Fakultas Perikanan dan Kelautan Universitas Riau \\ Kampus Bina widya Km 12,5 Simpang Baru, Pekanbaru, 28293 \\ Diterima tanggal: 12 Maret 2020 Diterima setelah perbaikan: 24 September 2020 \\ Disetujui terbit: 23 Desember 2020
}

\begin{abstract}
ABSTRAK
Penelitian ini bertujuan untuk mengetahui tingkat kemiskinan penerima PKH apakah penerima bantuan ini sudah tepat sasaran atau tidak, untuk mengetahui pendapatan nelayan di Kelurahan Bagan Hulu sebelum dan sesudah adanya PKH. Penelitian ini dilaksanakan pada bulan Mei 2018. Metode yang digunakan adalah metode survei dan wawancara kepada nelayan penerima $\mathrm{PKH}$, jumlah responden sebanyak 39 responden dengan pengambilan sampel secara acak. Untuk menganalisis pengaruh PKH terhadap tingkat pendapatan nelayan maka dilakukan uji-t. Hasil penelitian menunjukkan bahwa tingkat kemiskinan penerima PKH terdiri dari 92,30\% miskin dan 7,70\% tidak miskin. Dengan hasil uji-t 0,00<0,05 dapat dilihat bahwa ada pengaruh yang signifikan pada pendapatan sebelum dan setelah menerima $\mathrm{PKH}$. pendapatan rata-rata rumah tangga nelayan sebelum menerima PKH sebanyak Rp17.858.462,- per tahun, sedangkan pendapatan rata-rata setelah menerima PKH diperoleh sebesar Rp20.144.359,- per tahun atau sekitar 13\% dari pendapatan rumah tangga nelayan per tahunnya. Pengaruh PKH terhadap tingkat pendapatan masyarakat nelayan di Kelurahan Bagan Hulu sudah efektif berdasarkan tujuan programnya yakni menambah penghasilan rumah tangga miskin dalam meningkatkan taraf hidup.
\end{abstract}

Kata Kunci: Kelurahan Bagan Hulu; kemiskinan; program keluarga harapan

\begin{abstract}
This study aims to determine the poverty level of PKH recipients whether the recipients of this assistance have been on target or not, to determine the income of fishermen in Bagan Hulu Village before and after the existence of PKH. This research was conducted in May 2018. The method used was survey and interview methods to PKH recipient fishers, the number of respondents was 39 respondents with random sampling. To analyze the effect of PKH on the income level of fishers, the t-test was carried out. The results showed that the poverty rate of PKH recipients consisted of $92.30 \%$ poor and $7.70 \%$ non-poor. With the results of the t-test $0.00<0.05$, It can be seen that there is a significant effect on income before and after receiving PKH. The average income of fisher's households before receiving PKH was IDR 17,858,462 per year, while the average income after receiving PKH was IDR 20,144,359 per year or about 13\% of fisher's household income per year. The influence of PKH on the income level of the fishing community in Bagan Hulu Village has been effective based on the program objectives, that is; to increase the income of poor households in order to improve their standard of living.
\end{abstract}

Keywords: Urban Village of Bagan Hulu; poverty; program keluarga harapan 


\section{PENDAHULUAN}

Nelayan adalah masyarakat yang secara aktif melakukan pekerjaan mencari ikan dan tergolong prasejahtera dan selalu tersisih dari kebijakan pemerintah. Sangat banyak permasalahan yang diterima oleh nelayan, berawal dari minimnya penghasilan yang mereka peroleh sampai tidak adanya jaminan pekerjaan. Seperti halnya masyarakat buruh (proletar) dan petani, nelayan juga terjerat kemiskinan yang belum dapat dihapuskan dari muka bumi (Wahyono, 2004).

Menurut (Kusnadi, 2006) menyebutkan adanya beberapa faktor mengakibatkan kemiskinan, terdiri dari faktor alamiah serta non alamiah. Faktor alamiah berupa struktur alamiah sumber daya desa dan fluktuasi musim tangkap ikan. sedangkan faktor non alamiah berhubungan dengan terbatasnya teknologi penangkapan ikan, rendahnya jaringan pemasaran hasil perikanan serta tidak ditemukan koperasi nelayan, tidak terjadi keseimbangan di sistem bagi hasil serta tidak ada jaminan ketenagakerjaan.

Menurut (Indrayani, 2014) kemiskinan memberikan dampak pada pendidikan dan kesehatan. Salah satu program pemerintah dengan tujuan mensejahterakan masyarakat, yaitu Program Keluarga Harapan dengan cara memberikan bantuan tunai yang diberikan pada masyarakat miskin (Kementerian Sosial, 2012).

Menurut (Latifah, 2016) Wilayah Kabupaten Rokan Hilir sebagian besar adalah laut diantaranya terdapat Selat Malaka yang merupakan lalu lintas perdagangan internasional. Perekonomian Bagansiapiapi digerakkan oleh berbagai sektor ayang terdiri dari sektor perikanan, perkebunan, pertanian, budidaya burung walet, dan penggalangan kapal (Setyawati, 2008). Akan tetapi angka kemiskinan di Kabupaten Rokan Hilir sampai saat ini tergolong masih tinggi yakni $7,67 \%$. Kemiskinan di daerah Rohil di dominasi oleh masyarakat yang berada di daerah pesisir. Profesi masyarakat tergolong miskin ini diantaranya ada nelayan tradisional dan petani (Badan Pusat Statistik, 2018)

Kemiskinan merupakan masalah sentral yang paling sering dihadapi oleh oleh masyarakat nelayan yang mengakibatkan nelayan selalu dikategorikan sebagai kelompok masyarakat miskin bahkan sangat miskin (poorest of the poor). Hal ini disebabkan karena masyarakat nelayan diidentikkan sebagai kelompok masyarakat yang lekat dengan kemiskinan, tidak adanya kepastian nafkah dan krisis. Meningkatkan kesejahteraan masyarakat merupakan salah satu arah dari kebijakan perikanan dan kelautan. Populasi penduduk miskin daerah pesisir pada tahun 2011 diperkirakan mencapai 7,8 juta jiwa (KKP, 2011).

PKH merupakan skema jaminan sosial bagi masyarakat miskin bahkan sangat miskin dalam menambah akses serta mutu kesehatan dan pendidikan berdasarkan dengan melaksanakan kewajiban sebagaimana ketentuan dalam persyaratan selaku penerima $\mathrm{PKH}$. Secara internasional program ini dikenal dengan program bantuan tunai bersyarat. Persyaratan tersebut seperti kehadiran difasilitas pendidikan (anak yang masih sekolah), kehadirannya difasilitas kesehatan seperti: bagi anak balita, atau ibu hamil (Kemensos, 2012)

PKH merupakan program bersifat integratif, artinya PKH mengintegrasikan program-program lama yang sudah ada seperti (Rastra, KIS dan KIP) dan bersifat non tunai sehingga tidak mudah bagi masyarakat nelayan mengaksesnya, karena keterbatasan dalam penggunaan teknologi. Sebagian besar masyarakat baru mempunyai rekening bank ketika memperoleh bantuan PKH. Bantuan ini diharapkan mampu memberikan edukasi kepada masyarakat nelayan untuk digunakan dengan sebagaimana mestinya. Masyarakat nelayan yang mendapatkan bantuan tersebut agar tepat sasaran, efektif dan tepat jumlahnya.

Salah satu daerah pesisir yang masyarakatnya miskin yaitu nelayan di Kelurahan Bagan Hulu. Di Kelurahan Bagan Hulu terdapat masyarakat nelayan hidup dengan berkeluarga yang mempunyai banyak anak, namun penghasilan tergantung kepada iklim dan musim dengan mata pencaharian utama sebagai pencari ikan dengan pendapatan seadanya dan kebutuhan yang tidak mencukupi, sehingga menjadi tanggung jawab pemerintah dalam mengentaskan dan penanggulangan kemiskinan dengan adanya $\mathrm{PKH}$ yang diharapkan dapat mengangkat taraf hidup masyarakat miskin. PKH adalah program yang bertujuan mengurangi masyarakat miskin termasuk nelayan yang sebagian besar tergolong masyarakat miskin bahkan sangat miskin (Purwanto, 2012).

Masyarakat nelayan di Kelurahan Bagan Hulu memiliki penghasilan yang tidak dapat dipastikan berapa jumlah pendapatan yang mereka 


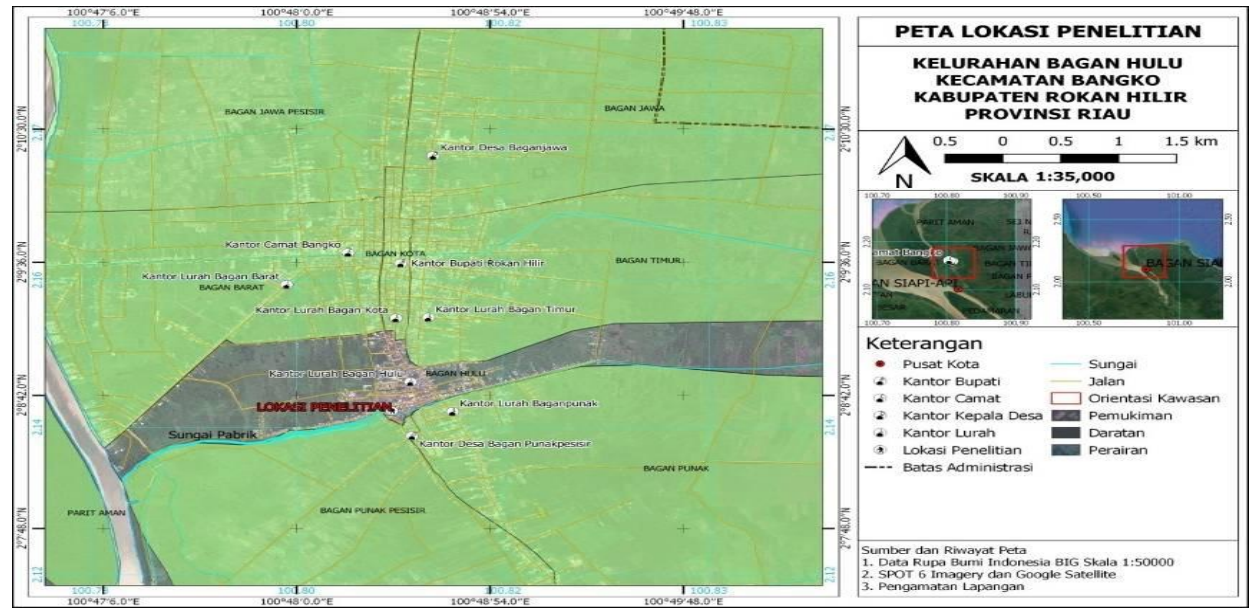

Gambar 1. Lokasi Penelitian.

Figure 1. Location of Research.

Sumber: (Badan Informasi Geospasial (BIG), 2018)/ Source: Geospatial Information Agency (BIG),2018

peroleh, sehingga bantuan PKH yang dirasakan oleh masyarakat nelayan sangat membantu sekali. Mengenai pembagian PKH kepada rumah tangga nelayan di Kelurahan Bagan Hulu diduga belum merata, masih ada beberapa masyarakat nelayan yang miskin belum mendapatkan Program Keluarga Harapan tersebut. Menurut (Rusydi, 2016) bantuan PKH dapat mempengaruhi mampu mempengaruhi peran pendidikan anak-anak di Kecamatan Indrajaya sekitar 96\%. Berdasarkan penjelasan tersebut menimbulkan ketertarikan penulis untuk meneliti terkait Pengaruh Program Keluarga Harapan Terhadap Tingkat Pendapatan Nelayan di Kelurahan Bagan Hulu Kecamatan Bangko Kabupaten Rokan Hilir. Tujuan dari penelitian ini yaitu untuk mengetahui tingkat kemiskinan penerima $\mathrm{PKH}$, untuk mengetahui pendapatan nelayan sebelum dan setelah adanya bantuan $\mathrm{PKH}$, melihat keberpengaruhan $\mathrm{PKH}$ pada tingkat pendapatan nelayan Kelurahan Bagan Hulu, Rokan Hilir.

\section{METODOLOGI}

\section{Lokasi dan Waktu Penelitian}

Penelitian ini dilakukan pada bulan Mei 2018 di Kelurahan Bagan Hulu Kecamatan Bangko Kabupaten Rokan Hilir. Lokasi penelitian ditentukan secara sengaja (purposive) karena Kelurahan Bagan Hulu merupakan wilayah dengan penduduk terbanyak sebagai Penerima Manfaat Program (PMP) PKH.

\section{Jenis dan Metode Pengambilan Data}

Metode yang digunakan adalah metode survei, wawancara mendalam secara struktur dan kuesioner selaku alat pengumpul data terhadap objek di lapangan secara langsung (Singarimbun, 2011). Jenis data yang dikumpulkan meliputi data primer dan sekunder. Adapun unit analisis dalam penelitian ini merupakan masyarakat nelayan penerima PKH di Kelurahan Bagan Hulu dan jumlah populasi yaitu sebanyak 62 rumah tangga, sementara pengukuran sampel menggunakan rumus Slovin (Sugiyono, 2011).

$$
n=\frac{N}{1+N(e)^{2}}
$$

Keterangan/Remarks :

$\mathrm{n}$ = Jumlah Responden/Number of respondents

$\mathrm{N}=$ Jumlah Populasi/Population

$\mathrm{e}=$ Batas Toleransi Error (0.1)/Error tolerance limit (0.1)

Berdasarkan hal tersebut diperoleh jumlah sampel:

$$
\begin{aligned}
& n=\frac{N}{1+N(e)^{2}} \\
& n=\frac{62}{1+62(0,1)^{2}} \\
& n=\frac{62}{1+0,62} \\
& n=38,27
\end{aligned}
$$


Berdasarkan perhitungan tersebut, maka peneliti membulatkan sampel responden sebanyak 39 responden. Dimana penentuan responden dipilih secara acak sederhana, setiap anggota populasi memiliki peluang yang sama untuk menjadi sampel penelitian.

\section{Metode Analisis}

Untuk mengukur tingkat kemiskinan penerima $\mathrm{PKH}$ ditentukan berdasarkan kriteria standar kemiskinan BPS untuk menentukan suatu masyarakat layak dikategorikan miskin. Menurut (Badan Pusat Statistik, 2018) pengukuran indikator dikemukakan dalam 14 (empat belas) pernyataan seperti luas tempat tinggal beserta jenis bangunannya, fasilitas MCK, sumber air minum, penerangan, bahan bakar, jumlah konsumsi daging, pembelian pakaian, jumlah makan dalam sehari, tempat berobat, sumber pendapatan kepala keluarga, pendidikan dan kepemilikan aset terdapat pada kuesioner yang harus direspon oleh masyarakat nelayan, setiap pernyataan diberi skor antara 1 - 14 sehingga diperoleh skor $\max =14 \mathrm{X}$ $3=42$, skor $\min =14 \times 1=14$. Berdasarkan nilai tersebut:

Range $=\frac{\text { skormax }- \text { skormin }}{3}$ atau Range $=\frac{42-14}{3}=9$.

Maka tingkat kemiskinan pada rumah tangga nelayan meliputi:

$$
\begin{aligned}
& 14-23 \rightarrow \text { Sangat Miskin/Extremely poor } \\
& 24-33 \rightarrow \text { Miskin/Poor } \\
& 34-43 \rightarrow \text { Tidak Miskin/Not poor }
\end{aligned}
$$

Untuk mengetahui perbedaan pendapatan masyarakat nelayan sebelum dan sesudah menerima bantuan PKH peneliti melakukan uji-t, sehingga diperoleh pengaruh $\mathrm{PKH}$ terhadap pendapatan rata-rata masyarakat nelayan, dengan merumuskan (Priyatno, 2013):

$$
t=\frac{r \sqrt{n-2}}{\sqrt{1-r^{2}}}
$$

Keterangan/ Remaks:

$r=$ Korelasi parsial/ Partial correlation

$\mathrm{n}=$ Jumlah sampel/ Number of samples

$\mathrm{t}=\mathrm{t}$ hitung (konsultasi $\mathrm{t}$ tabel)/ $t$ Count (consult $t$ table)

Untuk pengujian ini dilakukan hipotesis/ to test this hypothesis:
Ho: Tidak ada pengaruh antara tingkat pendapan nelayan dengan Program Keluarga Harapan (PKH)/ there is no influence between the income level of fishermen and the Program Keluarga Harapan (PKH).

$\mathrm{Ha}$ : Adanya pengaruh antara antara tingkat pendapatan dengan Program Keluarga Harapan (PKH)/ there is an influence between the level of income and the Program Keluarga Harapan (PKH).

Keputusan diambil berdasarkan/ Decisions are made based on:

Nilai signifikan $<0.05$ tolak $\mathrm{HO}$ / Significant value $<0,05$ reject $H O$

Nilai signifikan $>0.05$ terima $\mathrm{Ha} /$ Significant value $>0,05$ received $\mathrm{Ha}$

\section{HASIL DAN PEMBAHASAN}

\section{Keadaan Umum Lokasi Penelitian}

Kelurahan Bagan Hulu memiliki luas daerah $55 \mathrm{Km}^{2}$, terdapat $21 \mathrm{RT}$ dan $6 \mathrm{RW}$ serta dengan jumlah penduduk 10.071 jiwa dengan jumlah Kepala Keluarga 1.875 KK. Kelurahan Bagan Hulu secara umum keadaan geografis berupa tanah liat, rawa dan gambut. Sebagian masyarakatnya dengan mata pencaharian sebagai nelayan, buruh, dan berdagang. Adapun jumlah nelayan di Kelurahan Bagan Hulu sebanyak 415 orang dari 1.875 kk dengan 62 Rumah Tangga sebagai penerima bantuan $\mathrm{PKH}$.

Di lingkungan masyarakat pesisir, nelayan adalah kelompok yang paling menderita, miskin dan seringkali menjadi korban marginalisasi akibat kebijakan modernisasi perikanan. Sebagian besar nelayan miskin dikarenakan tidak mampu memenuhi kebutuhan keluarga yang banyak dengan penghasilan yang rendah.

\section{Tingkat Kemiskinan Penerima Program Keluarga Harapan}

Kategori kemiskinan diukur berdasarkan 14 kriteria miskin menurut standar BPS, yang mana terdapat beberapa indikator diantaranya: sandang, pangan, papan, sumber peneranga, air bersih, bahan bakar, kepemilikan aset, pendidikan terakhir kepala keluarga, serta pendapat. Hal ini dilihat berdasarkan rumah tangga penerima $\mathrm{PKH}$ dalam memenuhi kebutuhan tersebut.

Berdasarkan tingkat kemiskinan rumah tangga nelayan penerima PKH di Kelurahan Bagan 
Hulu terdapat $7,70 \%$ yang berada pada kategori Tidak Miskin dan $92,30 \%$ berada pada kategori Miskin. Hal ini menunjukkan bahwa sebagian rumah tangga nelayan berhak menerima bantuan dana $\mathrm{PKH}$ tersebut, yang mana program $\mathrm{PKH}$ telah dicanangkan pemerintah dalam mengatasi kesenjangan sosial khususnya sebagai perbaikan taraf hidup masyarakat miskin. Dana bantuan yang disalurkan kepada masyarakat ini merupakan dana yang sepenuhnya berhak dikelola oleh masyarakat itu sendiri, seperti tambahan dalam memenuhi kebutuhan sehari-hari, biaya pendidikan anak, biaya kesehatan bayi dan anak, tambahan modal kerja dan lain sebagaimya.

Secara umum hal yang menjadi tujuan utama dalam program $\mathrm{PKH}$ yaitu mensejahterakan sumber daya manusia, memberikan pemahaman prilaku peserta penerima PKH untuk mensejahterakan masyarakat, serta mengurangi masyarakat miskin. Menurut (Sunarti, 2016) pengukuran kesejahteraan mencakup aspek pendapatan, pengeluaran konsumsi, pekerjaan, kondisi akses kesehatan serta kemampuan untuk mengakses kebutuhan dasar (air bersih, sanitasi, kesehatan dan pendidikan). Tingkat kemiskinan penerima PKH disajikan pada Tabel 1.

Tabel 1 menunjukkan bahwa indikator masyarakat nelayan menurut tingkat kemiskinan terdapat $7,70 \%$ tidak miskin dan $92,30 \%$ tergolong miskin. Berdasarkan tingkat kemiskinan masih terdapat masyarakat nelayan yang tidak miskin sebagai penerima bantuan PKH. Kemiskinan yang dirasakan bagi keluarga contoh menurut
(Sumodiningrat, 1999) dikategorikan pada kemiskinan kultural yang lebih berakar pada budaya lokal dan golongan masyarakat tertentu.

\section{Ketepatan Sasaran}

Peserta PKH yaitu rumah tangga yang masuk kategori miskin. Penentuan rumah tangga miskin dimulai dengan validasi kemiskinan yang dilakukan oleh BPS melalui calon peserta penerima PKH. Terdapat 14 kriteria BPS, dan jika sembilan dari variabel itu terpenuhi maka rumah tangga tersebut dikategorikan sebagai keluarga kurang mampu atau miskin yang berhak menerima bantuan $\mathrm{PKH}$.

Tabel 2 menunjukkan bahwa terdapat 34 masyarakat nelayan yang berhak menerima bantuan $\mathrm{PKH}$, sedangkan 5 masyarakat nelayan yang tidak berhak menerima bantuan tersebut tetapi ditetapkan sebagan penerima Program Keluarga Harapan (PKH). Berdasarkan ketetapan Kementerian Sosial terkait 14 kriteria penerima PKH masih ada yang tidak tetap sasaran, ini disebabkan banyaknya ditemukan data yang salah. Data penerima merupakan data tiga tahun lalu, sehingga kehidupan ekonomi masyarakatnya saat ini sudah banyak yang berubah, sehingga ke depannya tidak lagi diberikan bantuan. Sejalan dengan penelitian (Saraswati, 2018) bahwa penyaluran bantuan PKH di Pekon Pandansurat belum sesuai pada sasaran tampak yang menerima PKH pun cukup sejahtera serta bisa memenuhi keperluannya sendiri sebanyak 5 dari 72 responden.

Tabel 1. Tingkat Kemiskinan Masyarakat Nelayan Penerima PKH.

Table 1. Poverty level of the recipient Community of PKH Fishers.

\begin{tabular}{lccc}
\hline \multicolumn{1}{c}{$\begin{array}{c}\text { Indikatorl } \\
\text { Indikator }\end{array}$} & Skor/Score & $\begin{array}{c}\text { Jumlah RT/ } \\
\text { Total RT }\end{array}$ & $\begin{array}{r}\text { Persentase/ } \\
\text { Percentage }\end{array}$ \\
\hline Tidak Miskin/ Not poor & $34-43$ & 3 & 7.70 \\
Miskin/ Poor & $24-33$ & 36 & 92.30 \\
Sangat Miskin/ Extremely poor & $14-23$ & 0 & 0 \\
Jumlah/Total & & 39 & 100 \\
\hline
\end{tabular}

Tabel 2. Rekapitulasi Responden Berdasarkan Jumlah Kriteria yang Dipenuhi. Table 2. Recapitulation of Respondents Based on Number of Criteria.

\begin{tabular}{ccc}
\hline $\begin{array}{c}\text { Jumlah Kriteria/ } \\
\text { Number of Criteria }\end{array}$ & $\begin{array}{c}\text { Jumlah Responden/ } \\
\text { Number of respondents }\end{array}$ & $\begin{array}{c}\text { Persentase/ } \\
\text { Percentage }\end{array}$ \\
\hline 11 & 3 & 7.69 \\
10 & 15 & 38.46 \\
9 & 16 & 41.03 \\
8 & 3 & 7.69 \\
7 & 2 & 5.13 \\
Jumlah/Total & $\mathbf{3 9}$ & $\mathbf{1 0 0}$ \\
\hline
\end{tabular}


Menurut (Widyanti, Suryahadi, Sumarto, \& Yumna, 2009) banyaknya jumlah anggota keluarga, maka besar pula peluang rumah tangga mengalami kemiskinan kronis. Kriteria miskin penerima $\mathrm{PKH}$ yaitu dengan jumlah sumber daya yang sangat minim, sementara besarnya beban keluarga mengharuskan keluarga untuk mempunyai sumber daya yang banyak. Hasil penelitian menunjukkan bahwa program PKH telah mampu mengurangi semua kebutuhan rumah tangga miskin (RTM). Meskipun belum dapat menuntaskan secara keseluruhan kemiskinan yang ada. Sejalan dengan (Rizal, 2017) bahwasanya pengaruh PKH terhadap kesejahteraan masyarakat Kabupaten Sidoarjo mempuyai nilai signifikansi pada golongan sangat kuat sekitar $89 \%$.

\section{Pendapatan Peserta Penerima PKH}

Pendapatan dapat digunakan sebagai tolak ukur kondisi ekonomi masyarakat, kegunaan dari konsep penghasilan dengan mengetahui semua nilai uang yang diperoleh masyarakat dalam waktu tertentu. Semakin besar pendapatan yang diterima maka semakin besar pula kemampuan suatu usaha untuk membiayai segala pengeluaran dan kegiatankegiatan yang akan dilakukan, penghasilan memiliki pengaruh terhadap keberlanjutan usaha (Samuelson \& Nordhaus, 2004).

PKH ini sudah ada sejak tahun 2007, akan tetapi responden peneriman bantuan $\mathrm{PKH}$ di Kelurahan Bagan Hulu sebagian besar dimulai sejak tahun 2014 hingga 2018 Pembayaran bantuan dilakukan empat tahap atau empat kali dalam satu tahun. Dana PKH sebesar Rp500.000 yang diberikan kepada peserta $\mathrm{PKH}$ sebagai bantuan tetap. Jika peserta memiliki anak berpendidikan SD/MI maka bantuan akan ditambah Rp250.000. Bertambah Rp700.000 jika peserta adalah ibu hamil/ menyusui dan memiliki anak usia dibawah 6 tahun sebesar Rp600.000. Bertambah lagi Rp700.000 jika peserta memiliki anak berpendidikan setara SMA/MA. Akan ditambah lagi jika peserta memiliki anak berpendidikan SMP/MTs sebesar Rp500.000. Peserta lansia tambahan bantuan yang diberikan sebesar Rp700.000 dan untuk peserta $\mathrm{PKH}$ yeng merupakan penyandang disabilitas berat maka bantuan akan ditambah Rp1.250.000. Bantuan dana $\mathrm{PKH}$ yang diterima peserta akan berbeda-beda jumlahnya sesuai dengan anggota keluarga yang dimiliki. Tetapi jika peserta PKH tidak menunaikan komitmen yang telah ditetapkan dalam tiga bulan lamanya, maka besarnya bantuan yang diterima berkurang Rp50.000 dibulan pertama, berkurang Rp100.000 untuk bulan kedua dan berkurang sebesar Rp150.000 pada bulan ketiga. Jika selama tiga bulan berturut-turut peserta masih tidak menunaikan komitmen sehingga dikeluarkan dari kepesertaan (Kementerian Sosial, 2012).

Pelaksanaan penyaluran bantuan $\mathrm{PKH}$ para peserta sama sekali tidak mendapatkan undangan secara resmi, hanya mengetahui informasi dari mulut ke mulut sehingga menyebabkan informasi yang diterima tidak efektif dan membuat penerima menjadi ragu dan bingung. Pendamping $\mathrm{PKH}$ hanya memberikan informasi kepada ketua kelompok saja, dan ketua kelompok yang memberitahukan kepada setiap anggotanya dan tidak ada surat edaran resmi.

Salah satu tujuan dari bantuan $\mathrm{PKH}$ ialah untuk meningkatkan pendapatan masyarakat miskin serta membantu mengurangi beban pengeluarannya. $\mathrm{PKH}$ secara perlahan diharapkan dapat mendorong kemandirian dan perubahan perilaku keluarga penerima $\mathrm{PKH}$ kedepannya (Suharto \& Thamrin, 2012). Besarnya nilai bantuan yang diberikan seharusnya memperhitungkan inflasi, karena PKH dirasakan belum mamadai untuk mengembangkan suatu usaha (Nainggolan, 2012).

Tabel 3. Perbandingan Pendapatan Rata-rata Nelayan Sebelum dan Sesudah Adanya PKH.

Table 3. A Comparison of the Average Income of Fishers Before and After the Existence of PKH.

\begin{tabular}{cccccc}
\hline \multicolumn{5}{c}{ Statistik Sampel Berpasangan/Paired Samples Statistics } \\
\hline & $\begin{array}{c}\text { Rata-rata/ } \\
\text { Mean }\end{array}$ & N & $\begin{array}{c}\text { Std. Deviasi/ } \\
\text { Std Deviation }\end{array}$ & $\begin{array}{c}\text { Rata-rata Kesalahan/ } \\
\text { Error Mean }\end{array}$ \\
Pasangan 1/ Pair 1 & $\mathrm{X}$ & $\begin{array}{c}17858461.54 \\
\end{array}$ & 39 & 3190246.269 & 510848.245 \\
& $\mathrm{Y}$ & 20144358.97 & 39 & 3385800.687 & 542162.013 \\
\hline
\end{tabular}


Tabel 4. Hasil Uji t-Test Pendapatan Nelayan Sebelum dan Sesudah Adanya PKH. Table 4. t-Test Tesult of Fishers Income Before And After the Existence of PKH.

\begin{tabular}{|c|c|c|c|c|c|c|c|c|}
\hline \multicolumn{9}{|c|}{ Uji Sampel Berpasangan/ Paired Samples Test } \\
\hline & \multicolumn{5}{|c|}{ Perbedaan Berpasangan/ Paired Differences } & \multirow{3}{*}{$\mathbf{T}$} & \multirow{3}{*}{ df } & \multirow{3}{*}{$\begin{array}{c}\text { Sig. } \\
\text { (2-tailed) }\end{array}$} \\
\hline & \multirow{2}{*}{$\begin{array}{c}\text { Rata-rata/ } \\
\text { Mean }\end{array}$} & \multirow{2}{*}{$\begin{array}{c}\text { Std. } \\
\text { Deviasi/ } \\
\text { Std. } \\
\text { Deviation }\end{array}$} & \multirow{2}{*}{$\begin{array}{l}\text { Std. } \\
\text { Kesalahan/ } \\
\text { Std. Error } \\
\text { Mean }\end{array}$} & \multicolumn{2}{|c|}{$\begin{array}{l}95 \% \text { Kesalahan Interval dari } \\
\text { Perbedaan } / 95 \% \text { Confidence } \\
\text { Interval of the Difference }\end{array}$} & & & \\
\hline & & & & $\begin{array}{c}\text { Menurunkan I } \\
\text { Lower }\end{array}$ & $\begin{array}{l}\text { Atas/ } \\
\text { Upper }\end{array}$ & & & \\
\hline air 1 & - Y -2285897.436 & 735110.869 & 117711.946 & -2524192.813 & -2047602.059 & -19.419 & 8 & .000 \\
\hline
\end{tabular}

Tabel 4 setelah dilakukan uji-t, nilai sig. (2-taited) yaitu 0,00 diperoleh kesimpulan $P(0.00)<\alpha(0.01)$ sehingga antara pendapatan sebelum dan setelah adanya bantuan $\mathrm{PKH}$ terdapat perbedaan yang signifikan. Penelitian ini menunjukkan bahwa program $\mathrm{PKH}$ dapat meningkatkan hasil pendapatan rumah tangga miskin dalam waktu yang cepat (Son, 2008).

\section{KESIMPULAN DAN REKOMENDASI KEBIJAKAN}

\section{Kesimpulan}

Hasil analisis menunukkan bahwa pengaruh $\mathrm{PKH}$ terhadap tingkat pendapatan masyarakat nelayan di Kelurahan Bagan Hulu sudah efektif dengan tujuan program untuk menambah penghasilan rumah tangga miskin dalam memenuhi kebutuhan hidup. Pendapatan nelayan sebesar Rp20.144.359,- per tahun atau sekitar 13\% dari pendapatan nelayan per tahunnya setelah adanya PKH. Terdapat penambahan pendapatan secara signifikan penerima bantuan $\mathrm{PKH}$. Untuk ketepatan sasaran penerima bantuan $\mathrm{PKH}$ di Kelurahan Bagan Hulu belum dikatakan efektif, dikarenakan masih ada ditemukan di lapangan masyarakat yang tergolong tidak miskin mencapai 7,70\% mendapatkan bantuan $\mathrm{PKH}$.

\section{Rekomendasi Kebijakan}

Diharapkan kepada lembaga yang memberikan bantuan $\mathrm{PKH}$ hendaknya tepat sasaran dan benar-benar ditujukan untuk meningkatkan taraf hidup masyarakat miskin. Perkara tersebut penting, disebabkan bantuannya cuma bersifat sementara dan lebih terfokus untuk memutuskan mata rantai kemiskinan setelahnya tidak diberikan lagi. Sedangkan masyarakatyang menerima bantuan PKH sebaiknya berkonsentrasi penuh dalam menggunakan uang bantuan tersebut dengan sebaik-baiknya.

\section{PERNYATAAN KONTRIBUSI PENULIS}

Dengan ini kami menyatakan bahwa kontribusi masing-masing penulis terhadap pembuatan karya tulis adalah: Deviasari dan Trisla Warningsih sebagai kontributor utama, Firman Nugroho sebagai kontributor anggota. Penulis menyatakan bahwa telah melampirkan surat pernyataan kontribusi penulis.

\section{UCAPAN TERIMA KASIH}

Alhamdulillah puji syukur saya ucapkan atas kehadirat Allah SWT karena berkat rahmat dan karunia-Nya yang tiada henti kepada saya, sehingga dapat menyelesaikan karya ilmiah ini. Terima kasih kepada Kemenristekdikti melalui Universitas Riau yang telah memberikan bantuan beasiswa BIDIK MISI kepada saya selama menjadi mahasiswi.

\section{DAFTAR PUSTAKA}

Badan Informasi Geospasial (BIG). (2018). Data Rupa Bumi Indonesia BIG Skala 1:5000. Indonesia.

Badan Pusat Statistik, R. (2018). Retrieved Oktober 23, 2018, from http://riaupotenza.com

Direktur Jenderal Perlindungan Sosial dan Jaminan Sosial, R. (2012). Pedoman Umum Program Keluarga Harapan. Jakarta.

Indrayani, F. K. (2014). Efektivitas Program Keluarga Harapan di Desa Sugihwaras Kecamatan Seradan Kabupaten Madiun. Jurnal Administrasi Negara, Vol 2(3) : 1-11.

Kementerian Sosial, R. (2012). Pedoman Umum Program Keluarga Harapan. Jakarta.

KKP. (2011). Pedoman Pelaksanaan Program Nasional Pemberdayaan Masyarakat Mandiri Kelautan dan Perikanan. Jakarta.

Kusnadi. (2006). Konflik Sosial Nelayan : Kemiskinan dan Perebutan Sumberdaya Alam. Yogyakarta: LKiS. 
Latifah, U. F. (2016). The Occupational Mobility of Fishing to Non Fishing in Bagan Hulu, Bangko District, Rokan Hilir Regency. JOM FISIP, 1-15.

Nainggolan, T. (2012). Program Keluarga Harapan di Indonesia : Dampak pada Rumah Tangga Miskin di Tujuh Provinsi. Jakarta: P3KS Press Cawang.

Perpres No 10 Tahun, 2. (2010). Tentang Percepatan Penanggulangan Kemiskinan. Jakarta.

Priyatno, D. (2013). Analisis Korelasi, Regresi dan Multivariate dengan SPSS. Yogyakarta: Gava Media.

Purwanto. (2012). Implementasi Kebijakan Publik, Konsep dan Aplikasinya di Indonesia. Yogyakarta: Gava Media.

Rizal, M. (2017). Pengaruh Program Keluarga Harapan Terhadap Kesejahteraan Masyarakat di Kabupaten Sidoarjo. Surabaya: UIN Sunan Ampel.

Rusydi. (2016). Pengaruh Program Keluarga Harapan Terhadap Partisipasi Pendidikan di Kecamatan Indrajaya. Journal of Economic Management \& Business, 77-83.

Samuelson, P., \& Nordhaus, W. (2004). IImu Ekonomi Makro. Jakarta: Media Global Edukasi.

Saraswati, A. (2018). Analisis Pengaruh Program Keluarga Harapan Terhadap Pengentasan Kemiskinan dalam Perspektif Ekonomi Islam. Lampung: UIN Raden Intan.

Setyawati, S. (2008). Pasang Surut Industri Perikanan Bagansiapiapi 1898-1936. Depok: UI.

Singarimbun. (2011). Metode Penelitian Survei. Jakarta: LP3ES.
Son, H. (2008, July 2). Conditional Cash Transfer ProgramsFilipina, Honduras, Meksiko.

Sugiyono. (2011). Petode Penelitian Pendidikan Pendekatan Kuantitatif, Kualitatif dan $R$ \& $D$. Bandung: Alfabeta.

Suharto, E., \& Thamrin, D. (2012). Program Keluarga Harapan Memotong Mata Rantai Kemiskinan Anak Bangsa. Jurnal Aspirasi, Vol 3(1): 12-13.

Sumodiningrat, G., Santosa, B., \& Maiwan, M. (1999). Kemiskinan: Teori, Fakta dan Kebijakan. Jakarta: Impac

Sunarti, E. (2016). Indikator Keluarga Sejahtera. Bogor: IPB.

Wahyono, A. (2004). Pemberdayaan Masyarakat Nelayan. Jakarta: Media Pressindo.

Widyanti, W., Suryahadi, A., Sumarto, S., \& Yumna, A. (2009). The Relationship Between Chronic Poverty and Household Dynamics. Jakarta. 